\title{
Case Report \\ Sickle Cell Beta-Plus Thalassemia with Subcapsular Hematoma of the Spleen
}

\author{
Suyash Dahal, ${ }^{1}$ Sumit Dahal, ${ }^{2}$ Dipesh K. C. Ghimire, ${ }^{2}$ Ebad Ur Rahman, ${ }^{2}$ and Eliza Sharma ${ }^{3}$ \\ ${ }^{1}$ KIST Medical College and Teaching Hospital, Lalitpur, Nepal \\ ${ }^{2}$ Interfaith Medical Center, Brooklyn, NY, USA \\ ${ }^{3}$ Maimonides Medical Center, Brooklyn, NY, USA
}

Correspondence should be addressed to Sumit Dahal; sumit.dahal@gmail.com

Received 22 September 2017; Accepted 14 November 2017; Published 14 December 2017

Academic Editor: Marie-Christine Kyrtsonis

Copyright $\odot 2017$ Suyash Dahal et al. This is an open access article distributed under the Creative Commons Attribution License, which permits unrestricted use, distribution, and reproduction in any medium, provided the original work is properly cited.

While splenic complications like hypersplenism, sequestration crisis, and infarction are commonly reported in sickle cell variants like sickle cell beta-plus thalassemia, splenic rupture with hematoma is rare. We present a case of a 32-year-old young male who presented with dull left upper quadrant pain who was found to have multiple subcapsular splenic lacerations and hematoma on abdominal imaging. Hemoglobin electrophoresis confirmed sickle cell beta-plus thalassemia in the patient. There was no history of trauma, and rest of the workup for possible cause of spontaneous rupture of spleen was negative. With the patient refusing splenectomy, he was managed conservatively. Clinicians need to be aware of this rare complication of sickle cell variants.

\section{Introduction}

Sickle cell disease (SCD) refers to a group of autosomal recessive disorders characterized by hemoglobin $\mathrm{S}$ variant of the beta-globin gene. It affects millions of people worldwide and is particularly most prevalent in people whose ancestors came from sub-Saharan Africa, Central America, South America, Saudi Arabia, India, and Mediterranean countries. Centers for Disease Control and Prevention estimates approximately 100,000 Americans to be affected by SCD, with occurrences of about 1 in every 365 births in African Americans and about 1 in every 16,300 births in Hispanic Americans [1].

Beta-thalassemia is an inherited hemoglobinopathy caused by beta-globin gene mutations that impair the production of one or both beta-globin chains. Depending on the degree of reduction in beta-globin synthesis, it is divided into beta-thalassemia major, beta-thalassemia intermedia, and beta-thalassemia minor. It is most prevalent in Mediterranean and Southeast Asian countries [2]. Newborn screening in California estimated its incidence to be 1.8 per 100,000 infants [3].
Sickle cell beta-thalassemia is a sickle cell variant syndrome and is characterized by the compound heterozygosity for sickle and beta-thalassemia genes. It is divided into sickle cell beta ${ }^{+}$thalassemia and sickle cell beta ${ }^{0}$ thalassemia based on a decrease or complete absence of beta-globin synthesis respectively. The gene frequency of hemoglobin $S$ and betathalassemia in African Americans are estimated to be 0.04 and 0.004, respectively [4]. Newborn screening for hemoglobinopathies in California between 1998 and 2006 found the incidence of sickle cell beta ${ }^{+}$thalassemia and sickle cell beta ${ }^{0}$ thalassemia to be 1.4 per 100,000 infants and 0.8 per 100,000 infants respectively [3]. The symptoms in patients with sickle cell beta ${ }^{+}$thalassemia are less frequent and less severe than those in patients with homozygous sickle cell disease or sickle cell beta ${ }^{0}$ thalassemia $[5,6]$. Splenic complications like hypersplenism, sequestration crisis, and infarction have been reported frequently in patients with SCD and its variants, including in sickle cell beta-plus thalassemia $[7,8]$. Splenic hematoma, however, has rarely been described before. Here, we present a case of a young man with sickle cell beta-plus thalassemia who presents with spontaneous splenic rupture with multiple subcapsular hematomas. 


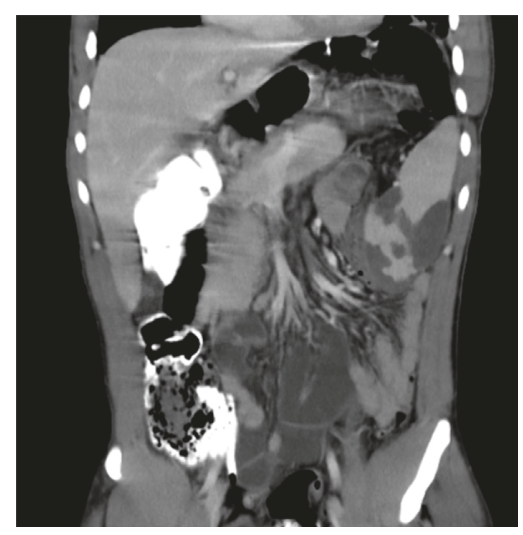

(a)

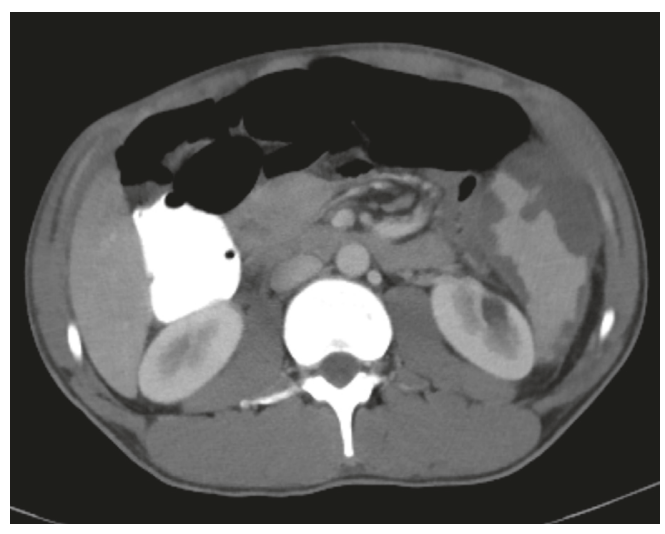

(b)

FIGURE 1: Coronal (a) and transverse (b) sections of the abdominal computed tomography scan showing multiple subcapsular hematoma in the spleen.

\section{Case Report}

Our patient was a 32-year-old male who came to the hospital complaining of dull left upper quadrant pain of 2 days duration. He denied any recent trauma. He had no fever, chills, sore throat, malaise, arthralgia, skin rash, or bleeding from the gums or any other site. The rest of the review of symptoms was negative. His past medical history was significant for an unclear sickling disorder. The patient himself reported having sickle cell trait and getting exchange transfusions as a child. His family history was significant for SCD in mother.

His vitals were stable at presentation. Physical examination was significant for splenomegaly and mild tenderness at the left upper quadrant of the abdomen with no icterus, hepatomegaly, or lymphadenopathy. Laboratory tests showed a leukocyte count of $10,400 / \mu \mathrm{L}$ (normal 4,500-11,000/ $\mathrm{L}$ ), hemoglobin of $13.4 \mathrm{gm} / \mathrm{dL}$ (normal 13.5-17.5 gm/dL), hematocrit of $41 \%$ (normal $41 \%-53 \%$ ) with mean corpuscular volume of $66.8 \mathrm{fL}$ (normal $80-100 \mathrm{fL}$ ), platelet count of $78,000 / \mu \mathrm{L}$ (normal $130,000-400,000 / \mu \mathrm{L})$, activated partial thromboplastin time of 35.7 seconds (normal 24.9-35.9 seconds), serum blood urea nitrogen of $13 \mathrm{mg} / \mathrm{dL}$ (normal $8-20 \mathrm{mg} / \mathrm{dL}$ ), serum creatinine of $1 \mathrm{mg} / \mathrm{dL}$ (normal $0.4-1.3 \mathrm{mg} / \mathrm{dL}$ ), total bilirubin of $2.2 \mathrm{mg} / \mathrm{dL}$ (normal $0.3-1.2 \mathrm{mg} / \mathrm{dL}$ ), aspartate aminotransferase of $28 \mathrm{IU} / \mathrm{L}$ (normal 15-41 IU/L), alanine aminotransferase of $33 \mathrm{IU} / \mathrm{L}$ (normal 17-63 IU/L), and serum alkaline phosphatase of 56 IU/L (normal 32-91 IU/L). Further workup for microcytic anemia showed a reticulocyte count of $1.96 \%$ (normal $0.5 \%-2 \%$ ), serum haptoglobin of $62 \mathrm{mg} / \mathrm{dL}$ (normal 34-200 mg/dL), serum lactate dehydrogenase of $245 \mathrm{IU} / \mathrm{L}$ (normal 98-192 IU/L), serum iron of $33 \mathrm{ug} / \mathrm{dL}$ (normal 38$169 \mathrm{ug} / \mathrm{dL}$ ), iron saturation of $16 \%$ (normal 15\%-55\%), serum ferritin of $269 \mathrm{ng} / \mathrm{mL}$ (normal 30-400 $\mathrm{ng} / \mathrm{mL}$ ), and a positive sickle cell screen. Subsequent hemoglobin electrophoresis revealed $17.5 \%$ of hemoglobin A (normal 94\%-98\%), 7.2\% of hemoglobin A2 (normal 0.7\%-3.1\%), 73.8\% of hemoglobin S (normal $0 \%$ ), and $1.5 \%$ of hemoglobin $\mathrm{F}$ (normal $0-2 \%$ ), which was suggestive of sickle cell beta-plus thalassemia. Computed tomography (CT) scans of the abdomen showed splenomegaly with multiple splenic subcapsular lacerations and hematomas (Figure 1). No other possible cause for spontaneous splenic rupture was found in the patient. His symptomatology, physical examination, and initial lab tests were not consistent with the common causes of splenic rupture like hematological malignancies, hemophilia, or malaria. Tests for Epstein-Barr virus, cytomegalovirus, human immunodeficiency virus, and hepatitis $\mathrm{A}, \mathrm{B}$, and $\mathrm{C}$ viruses returned negative. So, with the diagnosis of spontaneous splenic rupture with multiple subcapsular hematomas in a patient with sickle cell beta-plus thalassemia, the patient was initially managed conservatively with bed rest, analgesia, multivitamin, folic acid, and pneumococcal and meningococcal vaccinations with plans for splenectomy going forward.

However, on the fourth day of admission, the patient started to have cough, productive of yellowish sputum and palpitation. He had low-grade fever, tachycardia, and tachypnea. Repeat CT scan of the chest showed new bilateral lower lobe infiltrates. Arterial blood gas analyses in room air showed a $\mathrm{pH}$ of 7.46 (normal 7.35-7.45), $\mathrm{pCO}_{2}$ of $37 \mathrm{mmHg}$ (normal 35-45 mmHg), $\mathrm{pO}_{2}$ of $100 \mathrm{mmHg}$ (normal 75$100 \mathrm{mmHg}$ ), and $\mathrm{HCO}_{3}$ of $26.2 \mathrm{mmol} / \mathrm{L}$ (normal 18$24 \mathrm{mmol} / \mathrm{L}$ ). So, with the possible diagnosis of acute chest syndrome and/or hospital-acquired pneumonia, the patient underwent exchange transfusion with 2.8 liters of leukocytereduced red blood cell and broad-spectrum antibiotics. Subsequently his symptoms resolved, and his vital signs stabilized. The patient, however, refused splenectomy during his hospital stay. And with his hematological parameters stable, he was discharged home with a leukocyte count of $7,400 / \mu \mathrm{L}$, hemoglobin of $10.7 \mathrm{gm} / \mathrm{dL}$, hematocrit of $32.5 \%$, and platelets count of $263,000 / \mu \mathrm{L}$ at discharge.

\section{Discussion}

Splenic rupture and hematoma are mostly seen with blunt abdominal trauma. However nontraumatic cases in patients with splenomegaly or underlying hematological disorders have been described [9-11]. The most common causes of spontaneous rupture of spleen include infections like 
Epstein-Barr virus, malaria, human immunodeficiency virus, and hepatitis virus and hematological malignancies like leukemia and lymphoma [10, 12-17]. Cases of spontaneous rupture in patients with underlying hematological disorders like hemophilia have also been reported [18, 19].

Spleen is also commonly involved in different hemoglobinopathies and usually manifest with splenomegaly, hypersplenism, acute splenic sequestration, and splenic infarction $[7,8]$. Sickle cell beta-thalassemia is a sickle cell variant and is characterized by the compound heterozygosity for sickle and beta-thalassemia genes. Depending on the reduction or complete absence of beta-globin synthesis, they are divided into sickle cell beta ${ }^{+}$thalassemia and sickle cell beta $^{0}$ thalassemia. Patients with sickle cell beta-plus thalassemia have reduced synthesis of beta-globin chains rather than a complete absence and tend to have a more benign clinical course than those with sickle cell beta ${ }^{0}$ thalassemia or homozygous sickle cell disease [5, 20-22]. Splenic involvement occurs earlier and more frequently in patients with HbSS and sickle cell beta ${ }^{0}$ thalassemia as compared to sickle cell beta $^{+}$thalassemia [8]. There have been a few reported cases of spontaneous rupture of spleen in patients with sickle cell disease and trait $[23,24]$. However, cases of sickle cell beta-plus thalassemia presenting with spontaneous splenic rupture and splenic hematoma has rarely been described before our case [25]. Mukhopadhyay et al. described a similar case of splenic hematoma, which was possibly triggered by cocaine-induced vasospasm with acute splenic infarction and subsequent hemorrhage into the infarct. Our patient, however, had no clear triggers for the hematoma. It may have resulted from spontaneous bleed into chronic splenic infarcts that our patient was predisposed to due to his underlying hemoglobinopathy. Sickled red blood cells with irregular shape and propensity to adhere to blood vessels tend to clog blood vessels and lead to congestive splenomegaly and splenic infarcts $[26,27]$. This hypercoagulable state and the splenic effect may be synergized by the coexisting thalassemia [28].

In conclusion, splenic rupture and hematoma mimicking acute abdomen may rarely be the only presenting feature in patients with sickle cell disease and its variants like sickle cell beta ${ }^{+}$thalassemia as seen in our case. Clinicians, therefore, need to be aware of this rare complication and consider hemoglobin electrophoresis a part of the workup for unexplained cases of nontraumatic splenic hematoma.

\section{Conflicts of Interest}

The authors declare that there are no conflicts of interest regarding the publication of this paper.

\section{References}

[1] Sickle Cell Disease (SCD), (2016, August 31), November 2017, https://www.cdc.gov/ncbddd/sicklecell/data.html.

[2] J. Flint, R. M. Harding, A. J. Boyce, and J. B. Clegg, "1 The population genetics of the haemoglobinopathies," Bailliere's Clinical Haematology, vol. 11, no. 1, pp. 1-51, 1998.

[3] J. Michlitsch, M. Azimi, C. Hoppe et al., "Newborn screening for hemoglobinopathies in California," Pediatric Blood and Cancer, vol. 52, no. 4, pp. 486-490, 2009.
[4] A. G. Motulsky, "Frequency of sickling disorders in U.S. blacks," New England Journal of Medicine, vol. 288, no. 1, pp. 31-33, 1973.

[5] G. R. Serjeant and B. E. Serjeant, "Comparison of sickle cell beta o-thalassemia and sickle cell beta +-thalassemia in black populations," Birth Defects Original Article Series, vol. 18, no. 7, pp. 223-229, 1982.

[6] F. M. Gill, L. A. Sleeper, S. J. Weiner et al., "Clinical events in the first decade in a cohort of infants with sickle cell disease. Cooperative Study of Sickle Cell Disease," Blood, vol. 86, no. 2, pp. 776-783, 1995.

[7] A. Ashley-Koch, Q. Yang, and R. S. Olney, "Sickle hemoglobin (HbS) allele and sickle cell disease: a HuGE review," American Journal of Epidemiology, vol. 151, no. 9, pp. 839-845, 2000.

[8] H. A. Pearson, D. Gallagher, R. Chilcote et al., "Developmental pattern of splenic dysfunction in sickle cell disorders," Pediatrics, vol. 76, no. 3, pp. 392-397, 1985.

[9] M. E. Lieberman and M. A. Levitt, "Spontaneous rupture of the spleen: a case report and literature review," American Journal of Emergency Medicine, vol. 7, no. 1, pp. 28-31, 1989.

[10] S. J. Rhee, Y. Sheena, and C. Imber, "Spontaneous rupture of the spleen: a rare but important differential of an acute abdomen," American Journal of Emergency Medicine, vol. 26, no. 6, pp. 733.e5-733.e6, 2008.

[11] T. Drapanas, A. J. Yates, R. Brickman, and M. Wholey, “The syndrome of occult rupture of the spleen," Archives of Surgery, vol. 99, no. 3, pp. 298-306, 1969.

[12] M. Papesch and R. Watkins, "Epstein-Barr virus infectious mononucleosis," Clinical Otolaryngology and Allied Sciences, vol. 26, no. 1, pp. 3-8, 2001.

[13] H. E. Hynes, M. N. Silverstein, and K. J. Fawcett, "Spontaneous rupture of the spleen in acute leukemia. Report of 2 cases," Cancer, vol. 17, no. 10, pp. 1356-1360, 1964.

[14] T. W. Bauer, G. E. Haskins, and J. O. Armitage, "Splenic rupture in patients with hematologic malignancies," Cancer, vol. 48 , no. 12 , pp. $2729-2733,1981$.

[15] J. Zieren, M. Paul, M. Scharfenberg, and J. M. Müller, "The spontaneous splenic rupture as first manifestation of mantle cell lymphoma, a dangerous rarity," American Journal of Emergency Medicine, vol. 22, no. 7, pp. 629-631, 2004.

[16] H. I. Saba, W. Garcia, and R. C. Hartmann, "Spontaneous rupture of the spleen: an unusual presenting feature in Hodgkin's lymphoma," Southern Medical Journal, vol. 76, no. 2, pp. 247-249, 1983.

[17] S. B. Van Landingham, D. E. Rawls, and J. W. Roberts, "Pathological rupture of the spleen associated with hepatitis A," Archives of Surgery, vol. 119, no. 2, pp. 224-225, 1984.

[18] J. Brook and P. E. Newnam, "Spontaneous rupture of the spleen in hemophilia," Archives of Internal Medicine, vol. 115, no. 5, pp. 595-597, 1965.

[19] G. Mariani, V. Ziparo, G. de Rossi et al., "Spontaneous splenic haematoma in haemophilia. Report of a case and review of the literature (author's transl)," Haematologica, vol. 59, no. 2, pp. 205-211, 1974.

[20] O. S. Platt, B. D. Thorington, D. J. Brambilla et al., "Pain in sickle cell disease. Rates and risk factors," New England Journal of Medicine, vol. 325, no. 1, pp. 11-16, 1991.

[21] O. S. Platt, W. Rosenstock, and M. A. Espeland, "Influence of sickle hemoglobinopathies on growth and development," New England Journal of Medicine, vol. 311, no. 1, pp. 7-12, 1984.

[22] E. W. Smith and C. L. Conley, "Clinical features of the genetic variants of sickle cell disease," Bulletin of the Johns Hopkins Hospital, vol. 94, no. 6, pp. 289-318, 1954. 
[23] D. Sharma, "Sub capsular splenectomy for delayed spontaneous splenic rupture in a case of sickle cell anemia," World Journal of Emergency Surgery, vol. 4, p. 17, 2009.

[24] M. T. Shoemaker, A. C. Pitney, D. J. Harford, and J. A. Barker, "Acute splenic rupture in an adult with homozygous sickle cell anemia treated with chronic transfusions," Journal of Pediatric Hematology/Oncology, vol. 26, no. 12, pp. 849-851, 2004.

[25] S. Mukhopadhyay, S. Mukhopadhyay, and R. Malhotra, "Splenic hematoma in Hb S-beta+thalassemia," American Journal of Hematology, vol. 74, no. 3, pp. 224-225, 2003.

[26] N. J. Wandersee, R. C. Punzalan, M. P. Rettig et al., "Erythrocyte adhesion is modified by alterations in cellular tonicity and volume," British Journal of Haematology, vol. 131, no. 3, pp. 366-377, 2005.

[27] A. H. Al-Salem, Z. Naserullah, S. Qaisaruddin, H. Al-Abkari, A. Al-Faraj, and Y. M. Yassin, "Splenic complications of the sickling syndromes and the role of splenectomy," Journal of Pediatric Hematology/Oncology, vol. 21, no. 5, pp. 401-406, 1999.

[28] A. T. Taher, Z. K. Otrock, I. Uthman, and M. D. Cappellini, "Thalassemia and hypercoagulability," Blood Reviews, vol. 22, no. 5, pp. 283-292, 2008. 


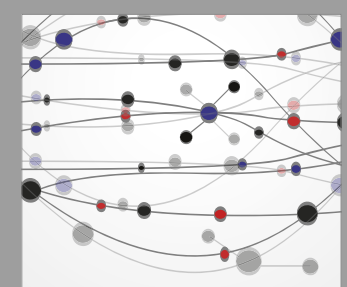

The Scientific World Journal
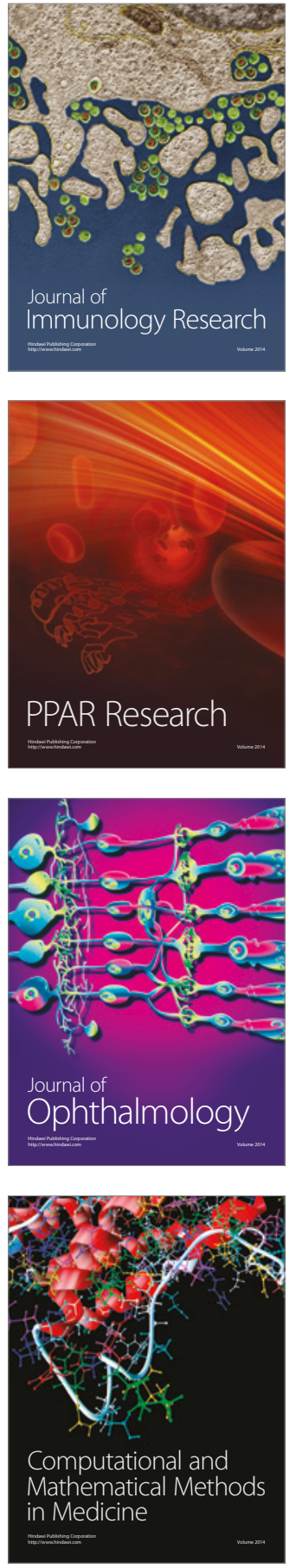

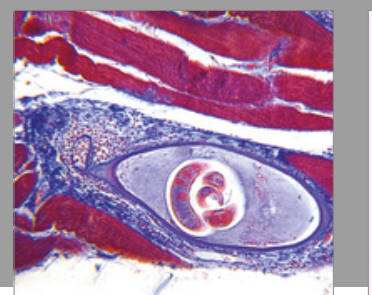

Gastroenterology Research and Practice
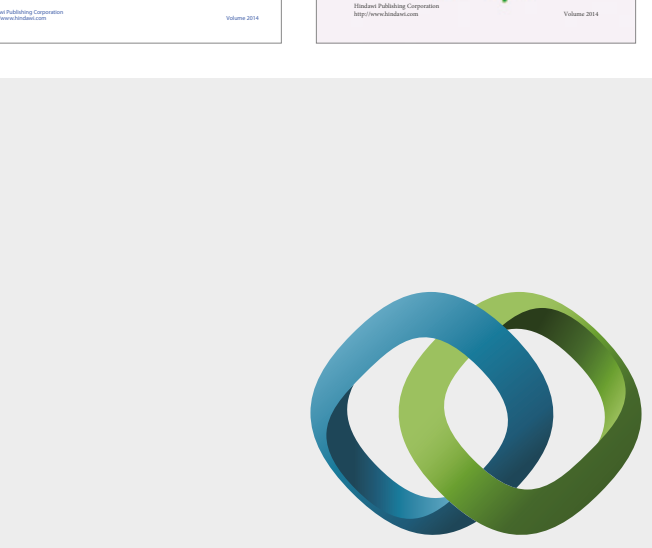

\section{Hindawi}

Submit your manuscripts at

https://www.hindawi.com
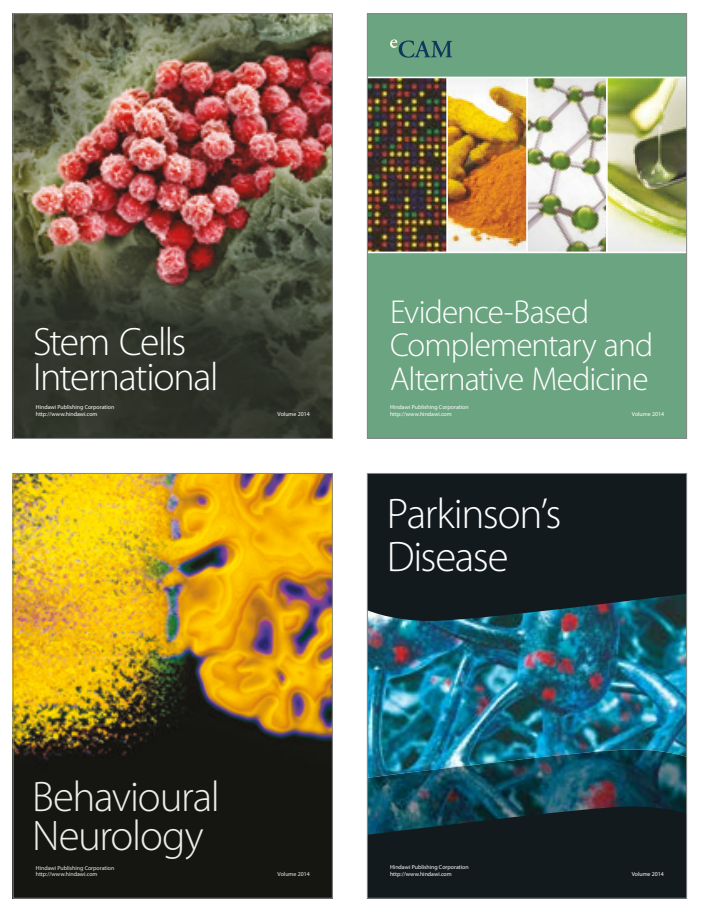
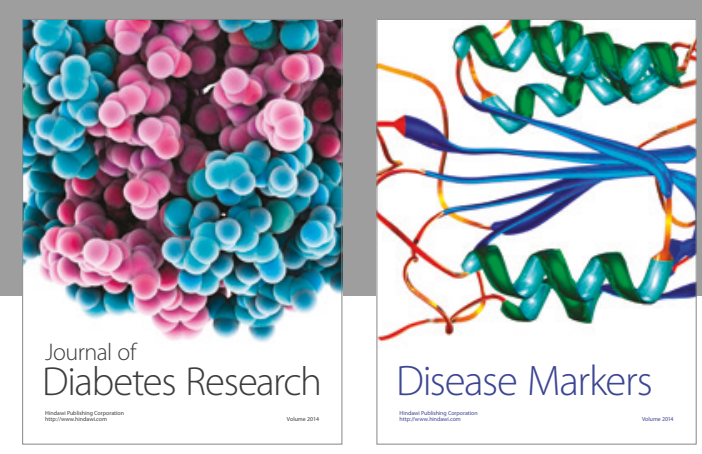

Disease Markers
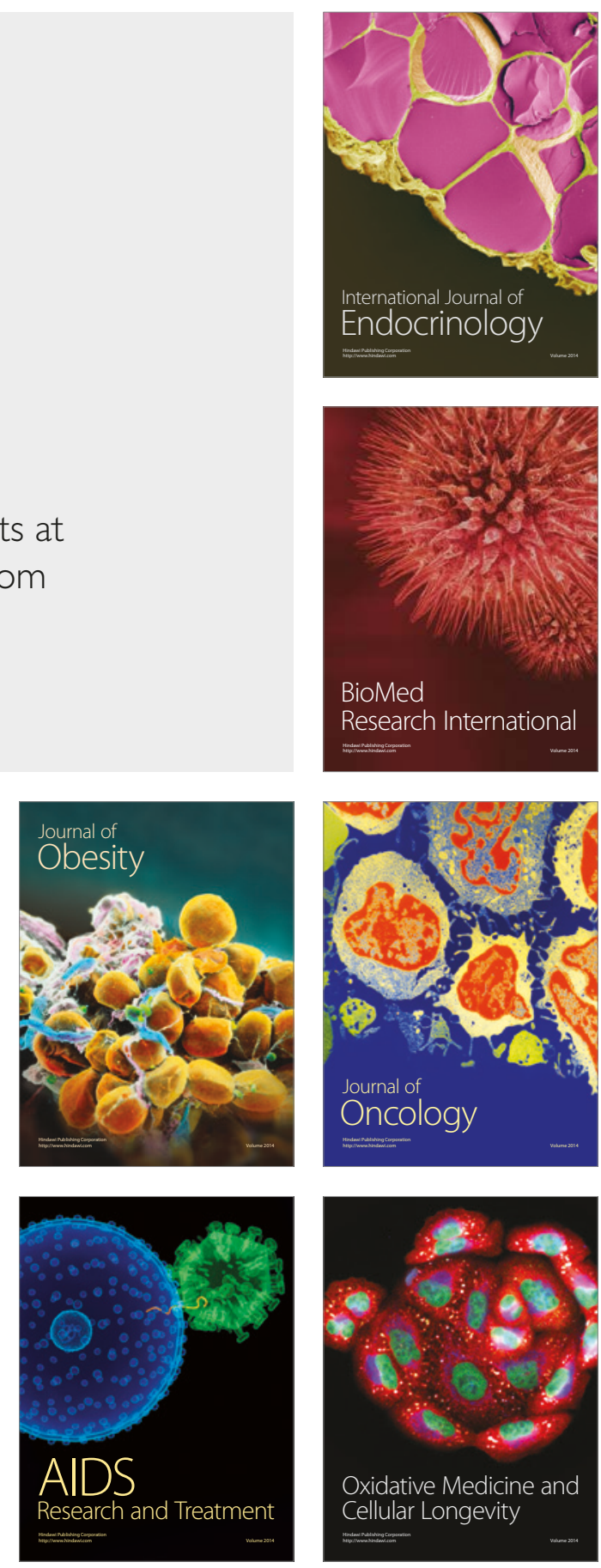